"An evaluation of the effectiveness of business incubation programs: a user satisfaction approach"

\begin{tabular}{|c|c|c|}
\hline \multirow{3}{*}{ AUTHORS } & \multicolumn{2}{|c|}{ Thobekani Lose (D https://orcid.org/0000-0001-6696-4468 } \\
\hline & \multicolumn{2}{|c|}{ R https://publons.com/researcher/AAA-9442-2022 } \\
\hline & \multicolumn{2}{|l|}{ Robertson K. Tengeh } \\
\hline ARTICLE INFO & \multicolumn{2}{|c|}{$\begin{array}{l}\text { Thobekani Lose and Robertson K. Tengeh (2016). An evaluation of the } \\
\text { effectiveness of business incubation programs: a user satisfaction approach. } \\
\text { Investment Management and Financial Innovations, 13(2-2), 370-378. } \\
\text { doi:10.21511/imfi.13(2-2).2016.12 }\end{array}$} \\
\hline DOI & \multicolumn{2}{|c|}{ http://dx.doi.org/10.21511/imfi.13(2-2).2016.12 } \\
\hline RELEASED ON & \multicolumn{2}{|l|}{ Thursday, 14 July 2016} \\
\hline JOURNAL & \multicolumn{2}{|c|}{ "Investment Management and Financial Innovations" } \\
\hline FOUNDER & \multicolumn{2}{|c|}{ LLC "Consulting Publishing Company "Business Perspectives" } \\
\hline & & $\begin{array}{l}\text { ニニ } \\
\text { =E- }\end{array}$ \\
\hline NUMBER OF REFERENCES & NUMBER OF FIGURES & NUMBER OF TABLES \\
\hline 0 & 0 & 0 \\
\hline
\end{tabular}

(C) The author(s) 2022. This publication is an open access article. 
Thobekani Lose (South Africa), Robertson K. Tengeh (South Africa)

\title{
An evaluation of the effectiveness of business incubation programs: a user satisfaction approach
}

\begin{abstract}
Business incubators were designed to sustain the deep-rooted image of entrepreneurs being self-reliant and by offering a broad spectrum of tailored services; it seeks to raise the success rate of small and medium size enterprises (SMEs) significantly. BIs have the characteristics to be completely dedicated to the success of a small business in its initial stages but, followed through, it puts in place the tools to achieve long-term success: space, funding, legal, accounting, computer services and other prerequisites to running a business, make BIs a one-stop shop for SMEs. This study has been conducted to establish if there has been a fairytale ending to the symbiotic relationship or whether the business incubator, like the SME, has had to traverse its own set of challenges towards achieving a happy union. The paper adopted a quantitative research approach in which the questionnaire was utilized as the relevant data collection tool. The Statistical Package for the Social Sciences (SPSS) software was used to analyze the data, with descriptive statistics at the end. As much as limited funding was reported to be a significant challenge that incubatees faced prior to joining the incubation programs, the results point to the fact that the need for multiple skills was the central force that seduced/lured the incubatees into the programs, but the majority of the participating respondents declare a complete lack of regret. Instead, they fully endorse the merits of the union, stating that BIs exists to effectively meet the objectives of SMEs.
\end{abstract}

Keywords: business incubators, user satisfaction, effectivenes of incubator programs, entrepreneurial skills, SMEs, South Africa.

JEL Classification: M1, L84.

\section{Introduction}

Globally, entrepreneurial activities - with its plethora of required skills - are widely recognized as significant contributors to economic growth. As a nod towards the contributions that Small and Medium size Enterprises (SMEs) make towards economic development, the South African government, like its international counterparts, saw the need to promote and support start-up enterprises (Masutha and Rogerson, 2014). Hence, as part of its commitment to economic restructuring, the SA government in 1995 rolled out a number of initiatives aimed at nurturing SMEs (Buys and Mbewana, 2007). Touted as a support structure to improve the survival rate of new and ailing businesses, South Africa adopted the business incubation model.

A number of researchers have noted that business incubators (BIs), especially in the developing countries, have to circumvent a number of challenges to equip SMEs with the requisite skills (Hutabarat and Pandin, 2014; Lose and Tengeh, 2015). At times, BIs lack the fundamental skills to fully contribute to the development of SMEs (Akcomak, 2009, p. 18). Given that the management of most business incubators do not stemfrom an

(C) Thobekani Lose, Robertson K. Tengeh, 2016

Thobekani Lose, Graduate Centre for Management, Faculty of Business and Management Sciences, Cape Peninsula University of Technology, South Africa.

Robertson K. Tengeh, Department of Entrepreneurship and Business Management, Faculty of Business and Management Sciences, Cape Peninsula University of Technology, South Africa. entrepreneurial background, BIs struggle to provide adequate support to SMEs (Lalkaka, 2002, p. 174; Aernoudt, 2004, p. 127; Peters, Rice and Sundararajan, 2004, p. 84; Adegbite, 2007, p. 164). This has resulted in most SMEs failing and being unable to sustain growth (Dba, Comm and Accy, 2008) with the resultant closure of a number of BIs. While researchers can rejoice in the addition of business incubation failure as a fresh area to study and analyze, it has compounded the existing problem of unsuccessful SMEs.

Despite the numerous resources invested in incubator programs by government and private organizations, their impact on SMEs is not well documented (Schwartz, 2009), especially in the context of South Africa (Lose and Tengeh, 2015). While a number of studies have explored the impact of entrepreneurial and business skills on organizational success and development (Pyysiainen, Anderson, McElwee and Vesala, 2006; Lesáková, 2012; Macheke and Smith, 2013; Salem, 2014), few have looked at the effectiveness of these incubators (Meru and Struwig, 2011). This paper needs the call for a study that evaluates the effectiveness of BIs (Bhabra-Remedios and Cornelius, 2003) in developing incubated SMEs with specific focus on South Africa (Lose and Tengeh, 2015). In attaining this goal, the current study shies away from the conventional approach to evaluating the effectiveness of incubation programs that focuses on the number of businesses incubated, the success rate, and the number of jobs created by incubated firms. Following Abduh, D'Souza, Quazi and Burley (2007), this paper adopts a user-centered 
approach to gauge the extent to which business incubation programs satisfy the needs of incubated SMEs? This goal was attained through a four-step process that involved the following:

a) an assessment of the challenges that the SMEs had prior to joining the program;

b) an evaluation of the reasons why SMEs join the programs;

c) an assessment of SME satisfaction with the services received; and

d) relating BI managers' skills to those required by their clients.

\section{Literature review}

1.1. Entrepreneurs. Nieman and Nieuwenhuizen (2009, p. 9) agree that an entrepreneur is a person who starts and manages a business to make a profit. Entrepreneurs assume risks, as they offer products or services, implement, identify and develop new business ideas (Groenewald, Mitchell, Nayager, Zyl, Visser, Train and Emanuel, 2006, p. 2). Highlighting the need for resources, Venter, Urban and Rwigema (2009, p. 6) see an entrepreneur as someone who takes advantage of an opportunity and then gathers various resources to exploit these opportunities that will be able to produce a product or service. The latter definition brings to the fore the centrality of resources and the ability to adequately mobilize them for the success of a business. It is the apparent lack of resources or inability to mobilize them that drive entrepreneurs to business incubation programs.

1.2. The incubation concept and business incubators. Many scholars of the concept would agree that small business incubation is a dynamic process that provides the platform for young and struggling firms to be nurtured during turbulent times. Derived from "nurturing" and likened to hatching a chicken's egg, the concept of incubation suggests providing guidance to new organizations, the main aim of which is hatching (Bergek and Norrman, 2008, p. 20). Hence, one may identify the primary role and objective of incubators to be promoting new venture creation and survival by providing them with the essential support (Lalkaka and Shaffer, 1999, p. 4). Concurring, Adegbite (2001, p. 157) notes that business incubators nurture SMEs when they provide the following range of services including:

- Space in fully built-up factory buildings on flexible and affordable terms.

- The provision of a comprehensive range of common services, including enterprise counselling and training, shared secretarial support, start-up financing and assistance with product development and marketing.

- Strict admission and exit rules, which are designed to ensure that the incubator concentrates its efforts on helping innovative, fast-growing business start-ups that are likely to have a significant impact on the local economy. Exit rules generally limit tenancy to a period of between three to five years, thereby ensuring a reasonable turnover of tenants.

- Hands-on assistance, including research and development (R\&D), advice and risk capital, usually through a network of external providers.

- Professional management, which involves monitoring tenant businesses closely against their business plans and ensuring that the incubator itself operates in a business-like fashion with the prospect of becoming financially self-sustaining (Scaramuzzi, 2002, p. 5; Mutambi et al., 2010, p. 5; Ndabeni, 2008, p. 262; Schwartz and Hornych, 2008, p. 439). Therefore, the incubation concept seeks efficient and effective means to link entrepreneurial talent and to accelerate growth in new emerging businesses (Grimaldi and Grandi, 2005; SEDA, 2013, p. 3).

1.3. The relationship between incubation and entrepreneurship. The implicit link between incubation and entrepreneurship has been suggested by a number of studies. For instance, the role that business incubators play in the development of businesses, particularly start-up and spin-off, is well documented (Hackett and Dilts, 2004; Khalid et al., 2011; Buys and Mbewana, 2007, p. 357). Relating the concept of business incubation to maternity clinics that nurture a prematurely born child by providing the essential live support mechanism, Triantafyllopoulou (2006, p. 9) notes that business incubators do the sameto entrepreneurs or businesses when they are most vulnerable. Hence, the main purpose of the business incubator is to address the needs of the incubatees and such support is more appropriate in the early stages of an entrepreneurial venture (Naude, 2010, p. 3).

On the one hand, Isabelle (2013, p. 19) mentions that incubators are most successful when their mission and goals are in line with the entrepreneur's needs, as well as sponsoring organizations. On the other hand, for entrepreneurs to maximize the benefits of incubator programs, Isabelle (2013, p. 19) cautions them to take into consideration the core offering of the BI before signing up. Beyond this, the entrepreneurs should ensure that the incubator offering is aligned to the entreprenur's needs. Furthermore, entrepreneurs should look at performance measures of the incubator company like number of clients, the survival rate of clients, 
occupancy rate, management effectiveness, royalties and investments raised (Isabelle, 2013, p. 19).

As support structures to entrepreneurs, it is no surprise that the performance and success of Bis are ultimately measured on the number of entrepreneurs or clients they have assisted and how they are performing in their business ventures (Centre for Strategy and Evaluation Services (CSES), 2002, p. 38). Hence, in order for BIs to fully contribute towards entrepreneurship, it is essential to understand and to manage the relationship between the two.

1.4. Business incubation in South Africa. According to Ndabeni (2008, p. 263), the concept of business incubation is fairly recent in developing countries and is still developing in South Africa. Mbewana (2005), in Cullen, Calitz and Chandler (2014, p. 80), agrees that the practice of business incubation in South Africa started in 1995 when the Small Business Development Corporation (SBDC) established a similar concept that was known as the hives of industry. These hives referred to a number of work stations that were gathered together to form a cluster of workshops that were created to bridge major economic obstacles in South Africa and while the hives played a key role in facilitating business skills and required resources between large and small companies, they were not known as incubators, because there was no time period for a company to move out of the hive's programs.

Currently, the South African business landscape is characterised by two incubation drives: technology centres and business incubation. Both have been established with the main purpose of stimulating economic development, particularly in the high technology SMEs (Ndabeni, 2008, p. 264). Additionally, black-owned SMEs in South Africa are a high priority area for development, upgrade and growth due to post-apartheid reconstruction (Rogerson and Rogerson, 1996, p. 33).

Aiming to give support to small, micro and medium businesses, the South African Government through agencies such as SEDA, established a number of business incubators operating nationally (SEDA, 2013, p. 3; SEDA, 2014; and DTI, 2014). These government agencies have the mandate and objective to empower business incubators and incubation centres. As such, these agencies provide financial assistance and advanced technological facilities (prototype) to BIs and encourage private business partnership with government to maintain the support of BIs (Baloyi, 2008, in Cullen et al., 2014, p. 80).

1.4. Skills requirement of business ventures. Regardless of the size of the venture, entrepreneurs require a number of skills to make a success. The skills required to develop and sustain the business are: technical skills, business management skills or entrepreneurship skills, as well as personal entrepreneurial maturity skills (Smith, Schallenkamp, Eichholz, 2007; Chang and Rieple, 2013, p. 227). Technical skills are defined as the ability to use knowledge with techniques such as the knowledge of accountancy, engineering and communication (Smit, Cronje, Brevis and Vrba, 2007, p. 17). The researcher believes that the business management or entrepreneurial skills also include management skills like planning, organizing, leading and controlling. While broad in scope, the general entrepreneurial skills that are likely to inhibit both business incubators and incubatees in South Africa include:

- Process skills: cover the ability to plan and organize, the ability to analyze tasks, evaluate and the ability to execute a plan. These skills are essential for both business incubators and incubated SMEs (Panikar and Washington, 2011, p. 29). Moreover, continual process and creative thinking forms part of development and innovation in the organization (Nieman and Nieuwenhuizen, 2009, p. 32).

- Personal skills: include innovation, initiative, risk-taking, and the ability to deal with the unknown with ease, accepting challenges, taking responsibility, and seeking opportunities in change (Pyysiainen, Anderson, McElwee and Vesala, 2006, p. 24).

- Interpersonal skills: these entail interacting with others effectively; communicating effectively, negotiating, influencing and demonstrating leadership (Pyysiainen et al., 2006, p. 24). The ability and expertize in performing such skills in business incubation will result in delivering the service and performing the nature of entrepreneurship activities.

\subsection{Factors that push or pull entrepreneurs to get} into incubator programs. Driven by a myriad of challenges and enticed by opportunities, SMEs seek relief in incubation programs. In order to provide services that match the needs of entrepreneurs and to ensure satisfaction for business incubators, it is essential for incubators to understand the motivation behind entrepreneur's involvement in their programs.

1.5.1. Limited skills. Kirsty (2010, p. 3) is of the view that in order to be successful in their ventures, entrepreneurs should have skills and expertize in the industry in which they are operating and should also be able to identify gaps and opportunities in the market to take advantage of them. To craftily spot opportunities and market trends requires someone who has knowledge of the inner workings of the industry and has a clear understanding of how to exploit the identified gaps. Apparently, this skill is sorely lacking 
in entrepreneurs, hence the need to be involved in incubation programs (Kirsty, 2010, p. 3).

1.5.2. Limited funding. Kirsty (2010, p. 3) identified access to finance as the greatest challenge faced by entrepreneurs which has contributed to them being involved in incubation programs. Financial institutions are quite nervous to lend money to new businesses due to the risk of failure associated with them; entrepreneurs should find a founding partner who will act as a mentor as well as give access to funding (Kirsty, 2010, p. 5). This can be achieved through business incubator programs, as it is easy for them to obtain funding from investors, banking institutions and the government.

1.5.3. Limited technology. In order to stay competitive in their ventures, there is a need to stay abreast with new technologies (Kirsty, 2010, p. 4). Business incubators give survivalist entrepreneurs access to better and improved technology as it is always evolving.

1.5.4. Access to business network. According to Kirsty (2010, p. 4), the market is not just an economic institution, it is also governed by social networks. They enable information sharing, resulting in new, innovative ideas. Access to business networks enable entrepreneurs to succeed, even if they have limited access to funders (Kirsty, 2010, p. 4). Business incubators have established networks; they can connect to entrepreneurs and run workshops where social interaction is encouraged. Although these factors motivate entrepreneurs to enrol in incubation programs, not all of them complete the programs (Beats, 2013). Most of the business incubators are either partly or fullyfunded publicly (Dee et al., 2012, p. 9). Incompletion of incubation programs results in the wastage of public resources which otherwise could be channelled elswhere.

\section{Research methodology}

The material for this investigation was drawn from primary and secondary sources. A quantitative approach was used to collect and analyze the data for this paper.

2.1. Population, sample and unit of analysis. The population is the total number of people that can be included in a study (Bertram and Christiansen, 2014 , p. 55). The population of this study was made up of all the business incubators and incubated SMEs that were identified from the database of Traction, with permission from the managing director. Traction is an organization that specializes in SME development strategy and programs. Representing that portion of the population of interest (Burns and Burns, 2008, p. 181), the sample for this study was drawn from the list of business incubators on Traction's database. Given that only five business incubators were on Traction's database, they were considered a reliable source for recruiting the study participants (incubatees). Given the list of business incubators and incubated SMEs with the contact details on the database from Traction, random sampling was possible (Singh, 2007, p. 102). From these business incubators, a representative sample of SMEs on the incubation programs was drawn for the survey; of the seventy questionnaires distributed, 28 were useful resulting in a $40 \%$ response rate.

Cooper and Schindler (2011, p. 166) define a unit of analysis as the entity being studied and which the researcher decides how the data should be analyzed for the study. For instance, people, groups or individuals could be a unit of analysis in a study. In this study, this unit of analysis comprised a group of individuals that included a mix of business incubation managers in the Cape metropolitan area and SMEs that were in the incubation program during the timeframe of the research. Individual characteristics such as the number of years of SMEs in the incubation program, education, gender, age, etc. were categorized in the research which outlines a picture of the group of individuals that were being studied.

2.2. Reliability, validity and data analysis. According to Bell (2005, p. 116), reliability is the extent to which a test produces similar results under constant conditions in all locations and the measurement must be consistent, while validity refers to a design instrument with the potential of achieving and measuring what is supposed to be achieved when measuring. To guarantee reliability and viability, a pilot study was conducted to refine the questionnaire and study protocol. The intended objectives of the study were evaluated in relation to the data collection. The process was repeat postdata collection and analysis to ensure that the findings are error free and unbiased.

Mouton (2001, p. 108) assert that data analysis is breaking up the data into manageable patterns, themes, connections and trends and to understand the various constitutive elements of the data through an inspection of the relationship between concepts and constructs to evaluate trends that can be identified or isolated. The Statistical Package for the Social Sciences (SPSS) software was utilized to analyze the data with descriptive statistics as the ultimate goal. Hence, the results are tabulated and presented in \% ages.

\section{Results and discussions}

The results of the quantitative research tool are presented in this section.

\subsection{Age distribution of respondents (incubatees).}

Table 1 below indicates a variety of age groups for SMEs within the incubation programs in various sectors in the Cape Metropolitan district who participated in this study. 
Table 1. Age distribution of respondents

\begin{tabular}{|c|c|c|c|c|c|}
\hline \multicolumn{2}{|c|}{ Age } & Frequency & $\%$ & Valid \% & Cumulative \% \\
\hline \multirow{4}{*}{ Valid } & 22 or less & 1 & 3.6 & 3.6 & 3.6 \\
\cline { 2 - 6 } & 22 to 30 & 9 & 32.1 & 32.1 & 35.7 \\
\cline { 2 - 6 } & 30 to 39 & 10 & 35.7 & 35.7 & 71.4 \\
\cline { 2 - 6 } & $39+$ & 8 & 28.6 & 28.6 & 100.0 \\
\cline { 2 - 6 } & Total & 28 & 100.0 & 100.0 & \\
\hline
\end{tabular}

The majority of respondents $(35.7 \%)$ were in the age category of 30 to 39 years, followed by those between 22 and 30 years $(32.1 \%)$ and $28.6 \%$ for respondents who were $39+$. Only $3.6 \%$ of the respondents were 22 years or less. The findings clearly show that young entrepreneurs are participating in the incubation program. It is clear that various age disciplines are seeking assistance from business-support structures. These results could be related to Masutha and Rogerson's (2014, p. 152) findings that the average age of entrepreneurs was 35 years and older. However, the main focus of the study was within the business incubation management.

3.1.1. Gender of respondents. The overwhelming majority $(83.1 \%)$ of respondents surveyed were males, while females represented only $17.9 \%$. Botha et al. (2006, p. 1) share similar views that previously disadvantaged designated groups, including women in entrepreneurship activities are likely to negatively affect the involvement of females in entrepreneurial actions. Moreover, the fact that most females in South Africa nowadays go to highly paid jobs in the corporate sector may also be the case against venturing into small-business management. Hence, Gwija et al. (2014) advance the view that efforts should be made to narrow the gap between participation of males and females and the latter should be motivated to start small businesses.

3.1.2. Period of the business operation. Incubated SMEs generally have a limited number of years in the incubation programs. The figure below illustrates the duration of operations:

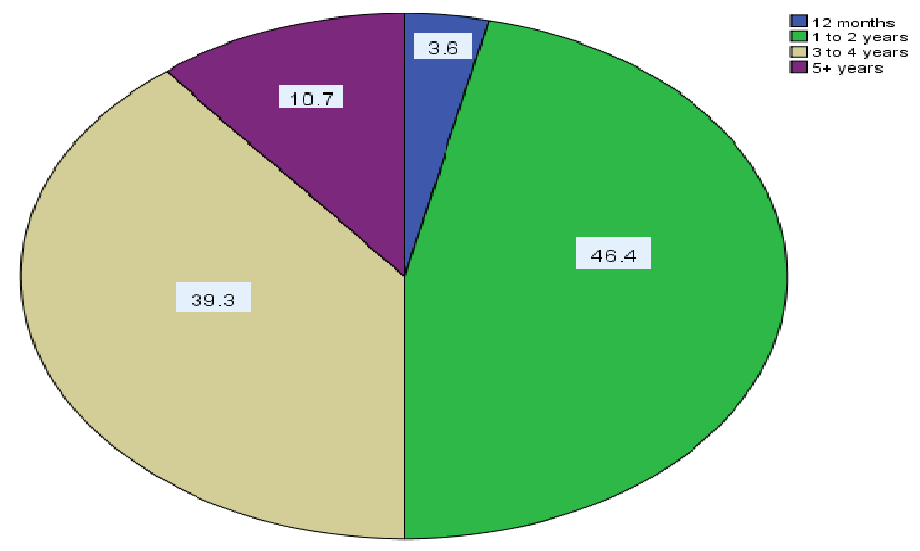

Fig. 1. Period of the business operation

The results above indicate and categorize the duration in which the respondents' businesses have been in the incubation program. A majority $(46.4 \%)$ of SMEs in the incubation program were between the ages of 1 to 2 years, followed by $39.3 \%$ of those who were between the ages of 3 to 4 years. Moreover, a few respondents $(10.7 \%)$ represented SMEs that were more than five years in the incubation program. Only 3.6\% represented those that had been in the program for 12 months. The study found that a majority of SMEs were indeed at the exit stage for graduation and those that had completed the program 2 to 3 years. According to Scaramuzzi (2002, p. 30), business incubators should seriously specify the time limits, and the cost, type and value of services that would be given to applicants during the incubation process. In South Africa, SMEs are still faced with a high rate of failure in their first three years in operation (Choto et al., 2014, p. 94). Hence, business incubators provide a nurturing environment to increase SMEs' prospects for surviving in their first three years of operation (Al-Mubaraki and Busler, 2010, p. 1; SEDA, 2013, p. 3; SEDA, 2014). Thus, in both developed and developing countries, the public and private business incubation period generally lasts for three years (Masutha and Rogerson, 2014, p. 60).

\subsubsection{The challenges that incubatees faced prior to} joining incubation programs. In reviewing the literature on the challenges that incubatees face prior to joining the incubation process, this research found that there are some key challenges that incubated SMEs face in running their businesses. The chart below shows such challenges. 


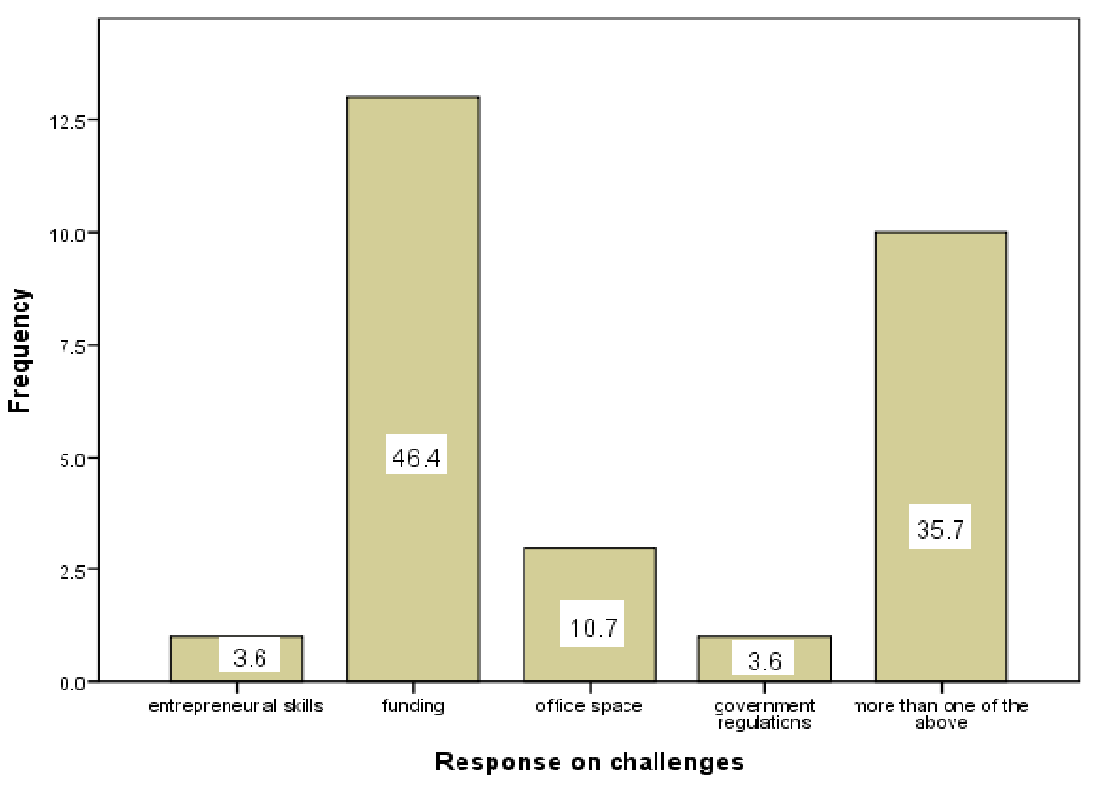

Fig. 2. Current challenges for incubated SMEs

The types of challenges respondents experience were categorized into: entrepreneurial skills, funding, office space, government regulations, and more that one of the above. The results of this study illustrates that a majority $(46.4 \%)$ of the participants indicated that funding is the major stumbling block, followed by $35.7 \%$ who indicated that their challenges were multiple, as illustrated above. This corresponds to the findings of Gwija, Eke, and Iwu (2014, p. 15) which proves that access to funding and business skills are the major challenges in running SMEs. Generally business incubators assist SMEs with office space; the findings of this study indicated that $10.7 \%$ of participants admitted to having office space challenges. Interestingly, the results specifically for both entrepreneurial skills and government regulations show that $3.6 \%$ of respondents indicated their concern over a lack of business skills. This is also consistent with the findings of other studies such as that of Masutha and Rogerson (2014a, p. 152) which indicates that incubated entrepreneurs lack the necessary business skills to fully contribute to the development of SMEs.

3.1.4. Objectives of enrolling in business incubation programs. Businesses join incubation programs for various reasons. The Table below shows the objectives of respondents in joining the incubation program.

Table 2. Objectives of enrolling in business incubation programs

\begin{tabular}{|c|l|c|c|c|c|}
\hline \multicolumn{2}{|c|}{ Objective enrolment } & Frequency & $\%$ & Valid \% & Cumulative \% \\
\hline \multirow{5}{*}{ Valid } & Growth & 5 & 17.9 & 17.9 & 17.9 \\
\cline { 2 - 6 } & Skills & 1 & 3.6 & 3.6 & 21.4 \\
\cline { 2 - 6 } & Finance & 1 & 3.6 & 3.6 & 25.0 \\
\cline { 2 - 6 } & Networking & 3 & 10.7 & 10.7 & 35.7 \\
\cline { 2 - 6 } & Other & 1 & 3.6 & 60.7 & 39.3 \\
\cline { 2 - 6 } & More than one of the above & 17 & 60.7 & 100.0 & 100.0 \\
\cline { 2 - 6 } & Total & 28 & 100.0 & & \\
\hline
\end{tabular}

The objectives in attending business incubation programs were categorized into growth, skills, finance, networking, other or etc. This indicates that the respondents' objectives were numerous. A majority of entrepreneurs in the incubation program who participated in this research $(60.7 \%)$ joined the incubation program to obtain a multiple of skills, followed by $17.9 \%$ of those who attended the program to grow their businesses. A total of $10.7 \%$ represented those who joined the program for a place to network. Interestingly, the respondents who joined the incubation program for finance and other reasons each made up $3.6 \%$ of the participants. The other respondents joined to have facilities to host their clients and hold meetings. According to Al-Mubaraki and Busler's (2010, p. 1) findings, incubator clients are seeking for assistance with a wide range of business activities. This could be an indication that the business incubation concept is crucial to overcome SMEs challenges. Masutha and Rogerson (2014b, p. 49) explain that in both developed and developing countries business incubation has been recognized as a strategic tool for helping entrepreneurial-based firms reduce the high failure rate of SMEs. 
3.1.5. The achievement of incubation goals. The result of the findings above show that a majority of respondents in this research $(78.6 \%)$ indicated that they have achieved their objectives in participating in the incubation program, joining the incubation would minimize the failure rate of SMEs' for those who attend incubation, while the remaining $21.4 \%$ indicated that they did not achieve their objective in joining the incubation program.

Drawing on the results noted in this section, entrepreneurs in the incubation program are happy and agree that being incubated minimizes their chances of failing, especially during the early and volatile stages of businesses. These results could be related to the above illustration made in the literature that the concept of a business incubator is crucial to SMEs' survival at the early operational stages, and business incubators have been adopted in South Africa as a vehicle for accelerating the SME economy (Masutha and Rogerson, 2014, p. 141). Therefore, the role of business incubators in facilitating the entrepreneurial skills requirements of small and medium sized enterprises should not be underestimated.

3.1.6. The incubator program effectiveness. In viewing the importance and effectiveness of the incubator programs to SMEs, this study interrogated the effectiveness of the incubated businesses. A large \% age $(60.7 \%)$ of the participants indicated that the incubator program is the best option for small business development and growth, while $36.9 \%$ of the respondents indicated that the program of incubation appeared not to be effective and efficient. Based on the results of the research, the majority agree that the incubation program should be taken seriously. Salem (2014, p. 854) also mentions that the business incubator program is one of the most important tools for helping start-up firms to survive during the early stages in business. These results are in agreement with Scaramuzzi's (2002, p. 24) findings, which conclude that, concerning incubation effectiveness, approximately $80 \%$ to $85 \%$ of incubated firms survive. Rogerson and Rogerson (1999, p. 34) also outline that incubators are a most important and sound model in providing necessary skills and resources to start-up firms. They suggest that incubators are either not taken seriously enough or they are not taken seriously at all.

3.1.7. Incubator ratings. Using the 10-point rating scale, where 1 and 10, respectively, represented not satisfied at all and very satisfied, the BIs were requested to rate their level of satisfaction with the level of service that they received while on the program. The results indicate that the majority (53.6\%) of the BIs noted an above average positive rating. It is interesting to note that $21.4 \%$ noted an average rating. All things being equal, this result suggests that business incubation is a sound model for developing and supporting SMEs. Prior studies have noted the importance of business incubators, as highlighted in the literature review (Buys and Mbewana, 2007, p. 356; Masutha and Rogerson, 2014a, p. 148; Masutha and Rogerson, 2014b:S61; Hutabarat and Pandin, 2014, p. 375; Scaramuzzi, 2002, p. 6; Ndabeni, 2008, p. 261; Stefanovic, 2008).

\section{Conclusions and recommendations}

For a long time entrepreneurship has been hailed as a significant contributor to an economy, yet the support systems in place ensuring the success of small business enterprises have been less than lacklustre. Are they just not taken seriously enough to warrant the attention? Heeding the cries of ailing SMEs, the South African government decided to take a leaf from the books of its international counterparts and adopt the novel notion of the "business incubation". Largely dependent on public funding, - directly or indirectly - business incubation is a business development strategy that aims to accelerate the process of formation, development, survivability and growth of new enterprises by providing clients with a wide range of business assistance that includes business counselling, networking opportunities and physical facilities. Driven by a myriad of challenges and enticed by opportunities, SMEs seek for relief in incubation programs. Notwithstanding the inherent ambitious intent, a select few of SMEs graduate from these programs. Anchoring the satisfaction debate in the users (incubated businesses), this paper assessed the efficacy of business incubation programs in the context of the Western Cape Province of South Africa.

In as much as limited funding was reported to be a significant challenge, the results weighed heavier in favour of the need for multiple skills that incubatees faced prior to joining incubation programs. Furthermore, the results proclaim that the majority of respondents are happy that their objectives in participating in the incubation program are met and endorse the effectiveness of the BIs concerned. Going by user satisfaction alone, the direct and indirect implications of these findings are that the business incubation programs are doing what they were created to do, though there is definitely room for improvement. To this end, these researchers suggest that, while govermnent should expand and direct more funds to business incubators, there is scope for the latter to improve on its offerring. For instance, BIs should strive to recruit only goaldriven entrepreneurs into their programs to ensure a smooth and timeous exit. Beyond this, BIs should be equipped with personnel who have the right skills to 
deal with their clients' concerns; this may entail constant evaluation and re-skilling of the incubator staff. It is also recommended that incubation managers who lack necessary entrepreneurial skills should enrol in business courses at local colleges or universities.

\section{Limitations and scope for future researchers}

The current study was limited only to business incubators in the Cape Metropolitan Area (CMA) which were registered on the database of an organization called Traction that promotes and develops SMEs in the Western Cape Province. Given the relatively small sample size utilized, future studies may benefit from larger samples. The current study recommends that further studies should consider the inclusion of SMEs that are outside incubation programs, particularly those that have completed the program. It may not be advisable to extend the findings of this paper to incubation programs outside the CMA. In conclusion, it is also recommended that future studies look at developing a framework for the effective start-up and operation of sustainable business incubators in South Africa.

\section{References}

1. Adegbite, O. (2001). Business Incubators and Small Enterprise Development: The Nigerian Experience, Small Business Economics, 17(3), pp. 157-166.

2. Aernoudt, R. (2004). Incubators: tool for entrepreneurship? Small Business Economics, 23(2), pp. 127-135.

3. Al-Mubaraki, H.M., Busler, M. (2010). Business Incubators: Findings from a Worldwide Survey, and Guidance for the GCC States. Global Business Review. SAGE.

4. Abduh, M., D'Souza, C., Quazi, A., Burley, H. (2007). Investigating and classifying clients' satisfaction with business incubator services, Managing Service Quality: An International Journal, 17, pp. 74-91.

5. Akcomak, I.S., Taymaz, E. (2004). Assessing the effectiveness of incubators: the case of Turkey. METU Economic Research Center, 1-18, October.

6. Akcomak, İ.S. (2009). Incubators as tools for Entrepreneurship Promotion in Developing countries (No. 2009.52). Research paper/UNU-WIDER.

7. Beats, W. (2013). Complexity, Uncertainty and Societal Responsibility: The paradigm of the emergent economy. While we cannot teach entrepreneurship, we can do so many interesting things. Graduate School of Business. University of Cape Town. Available at: http://gsbblogs.uct.ac.za/walterbaets/ [Accessed on 12 May 2012].

8. Bell, J. (2005). Doing Your Research Project. Berkshire: McHrwa-Hill.

9. Bergek, A., Norrman, C. (2008). Incubator best practice: A framework, Technovation, 28(1), pp. 20-28.

10. Bertram, C. and Christiansen, I. (2014). Understanding research. An introducing to reading research. Pretoria. Van Schaik Publisher.

11. Bhabra-Remedios R.K., Cornelius, B. (2003). Cracks in the Egg: improving performance measures in business incubator research paper for the Small Enterprise Association of Australia and New Zealand 16th Annual Conference of Small Enterprise Association of Australia and New Zealand, 28 September -1 October 2003.

12. Burns, R.B., Burns, R.A. (2008). Business Research Methods and Statistics Using SPSS. London. SAGE.

13. Buys, A.J., Mbewana, P.N. (2007). Key success factors for business incubation in South Africa: the Godisa case study, South African Journal of Science, 103, pp. 356-358.

14. Chang, J., Rieple, A. (2013). Assessing students' entrepreneurial skills development in live projects, Journal of Small Business and Enterprise Development, 20(1), pp. 225-241.

15. Centre of Strategy and Evaluation Services. (2002). Final Report: Benchmarking of Business Incubators. European Commission Enterprise Directorate General. United Kingdom.

16. Choto, P., Tengeh, R.K., Iwu, C.G. (2014). Daring to survive or to grow? The growth aspirations and challenges of survivalist entrepreneurs in South Africa, Environmental Economics, 5(4), pp. 93-101.

17. Dba, R. Comm, M., Accy, B. (2008). Business Incubator Services and Benefits: an In-Depth Investigation. Gibaran Journal of Applied Management, pp. 40-69.

18. Dee, N., Gill, D., Lacher R., Livesey, F., Minshall, T. (2012). A Review of Research on the Role and Effectiveness of Business Incubation for High-growth Start-Ups. Institute of Manufacturing. University of Cambridge.

19. DTI. (2014). The department of Trade and Industry, S.A. Program Guidelines: Incubation Support Program. Available at: http://www.thedti.gov.za/financial_assistance/financial_incentives [Accessed on 21 June 2014].

20. Grimaldi, R., Grandi, A. (2005). Business incubators and new venture creation: an assessment of incubating models, Technovation, 25(2), pp. 111-121.

21. Groenewald, J., Mitchell, B., Nayager, T., Zyl, J.V., Visser, K., Train, W. and Emanuel, B. (2006).Entrepreneurship fresh prospective. Cape Town: Lynn Koch.

22. Gwija, S.A., Eke, C.E. and Iwu, C.G. (2014). Challenges and Prospects of Youth Entrepreneurship Development in a Designated Community in the Western Cape, South Africa, Journal of Economics and Behavioral Studies, 6(1), pp. 10-20.

23. Hackett, S.M., Dilts, D.M (2004). A Real Options - Driven Theory of Business incubation, Journal of Technology Transfer, 29(1), pp. 44-54.

24. Hutabarat, Z., Pandin, M. (2014). Absorptive Capacity of Business Incubator for SMEs Rural Community Located in Indonesia's Village, Procedia - Social and Behavioral Sciences, 115, pp. 373-377. 
25. Isabelle, D.A. (2013). Key factors affecting a technology entrepreneur's choice of incubator or accelerator, Technology Innovation Management Review, pp. 16-22.

26. Kirsty, D. (2010). The State of Entrepreneurship in South Africa. Mount Nelson Hotel. White Paper Deliberation and Key Findings.

27. Lalkaka, R., Shaffer, D. (1999). Nurturing entrepreneurs, creating enterprises: technology business incubation in Brazil. In International conference on effective business development services 2-3.

28. Lalkaka, R. (2002). Technology business incubators to help build an innovation-based economy, Journal of Change Management, 3(2), pp. 167-176.

29. Lesákova, L. (2012). The Role of Business Incubators in Supporting the SME Start-up, Acta Polytechnica Hungarica, 9(3), pp. 85-95.

30. Lose, T., Tengeh, R.K. (2015). The Sustainability and Challenges of Business Incubators in the Western Cape Province, South Africa, Sustainability, 7(10), pp. 14345-14357.

31. Lesákova, L. (2012). The Role of Business Incubators in Supporting the SME Start-up, Acta Polytechnica Hungarica, 9(3), pp. 85-95.

32. Macheke, R., Smith, W. (2013). An analysis of business skills and training needs essential for business success in plastic manufacturing industries in developing nations: a case study of the Eastern Cape Province, South Africa, African Journal of Business Management, 7(20), pp. 2001-2010.

33. Masutha, M., Rogerson, C.M. (2014a). Small enterprise development in South Africa: the role of business incubators, Bulletin of Geography Socio-economic Series, 26, pp. 141-155.

34. Masutha, M., Rogerson, C. M. (2014b). Small business incubators: an emerging phenomenon in, Urbani Izziv, (25 (s), S47-S62.

35. Meru, A.K., Struwig. B. (2011). An Evaluation of the Entrepreneurs Perception of Business Incubation Services in Kenya. The Catholic University of Eastern Africa. Nairobi: Kenya.

36. Mouton, J. (2001). How to succeed in your master's and doctoral studies. Pretoria, South Africa: Van Schaik.

37. Mutambi, J., Byaruhanga, J.K., Trojer, L. and Buhwed, K.B. (2010). Research on the state of business incubation systems in different countries: lessons for Uganda, African Journal of Science, Technology, Innovation and Development, 2(2), pp. 190-214.

38. Nieman, G. and Nieuwenheuizen, C. (2009). Entrepreneurship. A South African Perspective. 2nd Ed. Cape Town: Interpak Books.

39. Ndabeni, L.L. (2008). The contribution of business incubators and technology stations to small enterprise development in South Africa. Development Southern Africa, 25(3), pp. 259-268.

40. Ndedi, A.A. (2009). Entrepreneurship training and job creation in South Africa: are tertiary institutions filling the gap? Journal of Contemporary Management, 6, pp. 463-470.

41. Peters, L., Rice, M., Sundararajan, M. (2004). The Role of Incubators in the Entrepreneurial Process, Journal of Technology Transfer, 29, pp. 83-91.

42. Pyysiainen, J., Anderson, A., McElwee, G., Vesala, K. (2006). Developing the entrepreneurial skills of farmers: some myths explored, International Journal of Entrepreneurial Behavior and Research, 12(1), pp. 21-39.

43. Salem, M.I. (2014). The Role of Business Incubators In The Economic Development Of Saudi Arabia, International Business and Economics Research Journal, 13(4), pp. 853-860.

44. Scaramuzzi, E. (2002). Incubators in developing countries. Status and Development Perspectives. The World Bank. Washington DC: Info Dev.

45. Schwartz, M. and Hornych, C. (2008). Specialization as strategy for business incubators: An assessment of the Central German Multimedia Center, Technovation, 28(7), pp. 436-449.

46. Schwartz, M. (2009). A multidimensional evaluation of the effectiveness of business incubators: an application of the PROMETHEE outranking method, Environment and Planning C: Government and Policy, 27, pp. 1072-1087.

47. SEDA. Small Enterprise Development Agency. (2013). IMBADU. 10th Ed. Pretoria: Official Quarterly Publication, 1-10 November - March 2013.

48. SEDA. (2014). Small Enterprise Development Agency (SEDA). Available at: http://www.seda.org.za [Accessed on 21 June 2014].

49. Singh, K. (2007). Quantitative Social Research Methods. New Delhi: Sage.

50. Smit, P.J., Cronje, G.J., Brevis, T. and Vrba, M.J. (2007). Management Principles, a Contemporary Edition for Africa. 4th edition. Cape Town, South Africa: Jutaand Co.

51. Stefanović, M., Devedžić, G., Eric, M. (2008). Incubators in Developing Countries: Development Perspectives. In 2nd International Quality Conference, 12-15 May 2008. 